\title{
Поллютанты и канцерогенные вещества в атмосфере Воронежа
}

\author{
Л.М. Акимов ${ }^{\square}$, Е.Л. Акимов \\ Воронежский государственный университет, Российская Федераџия \\ (394018, г. Воронеж, Университетская пл., 1)
}

\begin{abstract}
Аннотация: Цель исследования - провести пространственно-временной анализ результатов мониторинга за состоянием атмосферного воздуха города Воронежа.

Maтериаль и методы. В статье представлены результаты анализа ежедневных данных мониторинга «Воронежского центра по гидрометеорологии и мониторингу окружающей среды» за содержанием загрязняющих веществ в атмосферном воздухе города Воронежа на 5 стационарных станциях наблюдений, работающих в соответствии с требованиями РД 52.04.186-89 за период с 2015 по 2019 годы. Методология исследования базируется на картографическом анализе распределения основных поллютантов и их сравнении с критериальными значениями, определенными в руководящих документах. Оценка особенностей загрязнения воздушного бассейна осуществлялась с помощью комплексного индекса загрязнения атмосферы (ИЗА), рекомендуемого требованиями гигиенических нормативов ГН 2.1.6.3492-17.

Результаты и обсуждение Результатом исследования явилось установление особенностей пространственного и временного распределения полей загрязнения различными поллютантами, а также изучена их зависимость от сезонов года. Осуществлено картографирование исследуемых загрязнителей на территории города Воронежа и установлена их сезонная динамика.

Заключение. В пространственном распределении основных поллютантов на территории города Воронежа наблюдается устойчивая локализация очагов загрязнения, обусловленная функциональной структурой города. Для отдельных поллютантов выражена сильная зависимость концентрации от сезона года, что указывает на зависимость концентрации загрязняющих веществ от погодных условий и, в первую очередь, от термического режима.
\end{abstract}

Ключевые слова: концентрация, загрязняющие вещества, поллютанты, канцерогенные вещества.

Источник финансирования: «Исследование выполнено при финансовой поддержке Российского научного фонда, проект № 20-17-00172».

Для цитирования: Акимов Л. М., Акимов Е.Л. Поллютанты и канцерогенные вещества в атмосфере Воронежа // Вестник Воронежского государственного университета. Серия: География. Геоэкология, 2021, № 4, с. 77-87. DOI: https://doi.org/10.17308/geo.2021.4/3753

\section{ВВЕДЕНИЕ}

Загрязненность атмосферного воздуха крупных городов, к которым относится город Воронеж - основной фактор, влияющий на здоровье и жизнедеятельность населения. Поэтому основное внимание природоохранных организаций направлено на обеспечение чистоты воздушного бассейна. Данная проблема многофакторная, включающая как природную, так и антропогенную составляющую. Концентрация загрязняющих веществ в атмосфер- ном воздухе зависит от большего числа параметров. Мониторинг состояния чистоты атмосферного воздуха - важная социальная задача. Совершенствование системы мониторинга за количеством выбросов поллютантов в атмосферу, проведение анализа их пространственного и временного распределения, а также изучение распространения канцерогенов в воздухе города - задача крайне важная.

Теоретические обоснование и подходы к изучению данной проблематики представлены в

(C) Акимов Л. М., Акимов Е. Л., 2021

凶 Акимов Леонид Мусамудинович, e-mail: ak163@bk.ru Контент доступен под лицензией Creative Commons Attribution 4.0 License. 
трудах М.Е. Берлянда, Э.Ю. Безуглой [5, 6, 7], Е.Н. Кузнецовой [9], Н.И. Акунина [4].

Влияние метеорологических элементов на состояние окружающей среды отражено в работах Л. М. Акимова и др. [1-3], С. А. Куролапа [11].

Отдельно следует выделить исследования, посвященные влиянию загрязняющих веществ на состояние здоровья населения $[8,10,11,12]$.

\section{МАТЕРИАЛЫ И МЕТОДЫ}

Мониторинг за состоянием окружающей среды в Воронеже осуществляется Воронежским областным центром по гидрометеорологии и мониторингу окружающей среды на 5 стационарных станциях наблюдений, работающих в соответствии с требованиями РД 52.04.186-89. Станции подразделяются на «промышленные» вблизи предприятий (посты № 1, 8, 9, 10) и «авто» вблизи автомагистралей в районе с интенсивным движением транспорта (пост № 7). Посты центра находятся по адресам: ул. Ростовская, 44 - пост наблюдения № 1; ул. Лебедева, 2 - пост № 7; ул. Ворошилова, 30 - пост № 8; ул. Л. Рябцевой, 51-Б - пост № 9; ул. 9 Января, 49 - пост № 10. Регистрация содержания загрязняющих веществ в атмосферном воздухе осуществляется по ограниченному кругу загрязнителей: оксид углерода, диоксид серы, диоксид азота, взвешенные вещества, формальдегид, фенол.
В статье представлены результаты анализа ежедневных наблюдений стационарных постов города Воронежа за период с 2015 по 2019 годы. Общий объём выборки составил более 1800 случаев.

Критерии загрязнения атмосферного воздуха рекомендованы СанПиН 1.2.3685-21 «Гигиенические нормативы и требования к обеспечению безопасности и (или) безвредности для человека факторов среды обитания», устанавливающими для ряда веществ новый норматив - ПДК среднегодовая, обеспечивающая допустимые уровни риска при хроническом (не менее 1 года) воздействии.

\section{РЕЗУЛЬТАТЫ И ОБСУЖДЕНИЕ}

В Воронеже находится большое количество как стационарных, так и передвижных источников загрязнения воздушного бассейна. Распространение загрязнения пылью и канцерогенными веществами обусловлено в основном особенностями городской застройки.

По информации Воронежского центра по гидрометеорологии и мониторингу окружающей среды индекс суммарного загрязнения воздуха Воронежа, рассчитанный по 17 ингредиентам, в 2019 году увеличился по отношению к 2018 году и составил $10,9^{1}$. Увеличение концентраций загрязняющих веществ наблюдалось по пыли, окиси азота, формальдегида в районе промышленно-

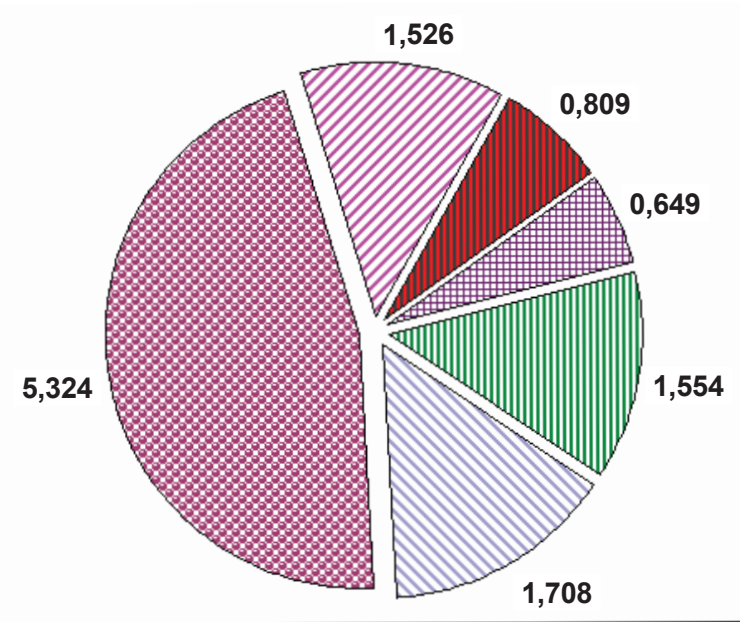

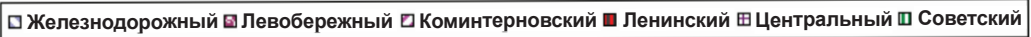

Puc. 1. Валовой выброс загрязняющих веществ от стационарных источников по различным районам Воронежа за 2019 год²

[Fig. 1. Gross pollutant emissions from stationary sources by different districts of Voronezh for 2019]

\footnotetext{
${ }^{1}$ Доклад о состоянии окружающей среды на территории Воронежской области в 2018 году. Воронеж: Центр духовного возрождения Черноземного края, 2019. 240 с.

Доклад о природоохранной деятельности городского округа город Воронеж в 2017 году / Управление экологии администрации городского округа город Воронеж. Воронеж: 2018. 58 с.

${ }^{2}$ Доклад о состоянии окружающей среды на территории Воронежской области в 2018 году. Воронеж: Центр духовного возрождения Черноземного края, 2019. 240 с.
} 
го узла ТЭЦ-1, АО «Воронежсинтезкаучук» (пост № 7, ул. Лебедева, 2). Анализ проб атмосферного воздуха на стационарных постах наблюдения и пяти маршрутных точках превышал максимально-разовые концентрации в воздухе города по пыли 4,4 ПДК, оксиду углерода - 2,8 ПДК, диоксиду азота - 1,3 ПДК, формальдегиду - 1,2 ПДК. Наибольшее увеличение средних концентраций загрязняющих веществ, регистрировалось в теплый период года ${ }^{3}$. Валовый выброс загрязняющих веществ по районам города Воронежа за 2019 год от стационарных источников представлен на рисунке 1 .

Наибольшая концентрация загрязнений наблюдается в Левобережном районе Воронежа. За период 2017 - 2019 годы кратность превышения ПДКс.с. составила от 1,1 до 5,0 и более раз. Доля проб атмосферного воздуха по приоритетным веществам (\%) по годам $(2017,2018,2019)$, превышающая более 1,0-2,0 ПДКс.с. с учетом динамики показателя к 2015 году, составила по диоксиду азота - 5,2; 8,8; 2,6 - (понижение); взвешенные вещества - 3,8; 3,1; 3,4 - (понижение); фенол 2,$1 ; 1,5 ; 1,5$ - (понижение); озон - 4,0; 12,0; 4,0 (понижение-повышение); диоксид серы - 0,$9 ; 0,8$; 0,0 - (понижение); оксид углерода - 0,$0 ; 3,8 ; 0,8-$ (повышение); формальдегид - 0,0; 0,38; 1,1 - (повышение); стирол - 2,5; 7,5; 0,0 - (понижение) $)^{4}$.

Наибольший вклад в уровень загрязнения воздушного бассейна вносят диоксид азота, взвешенные вещества и фенол.

Анализ распределения пыли на территории Воронежа, представленный на рисунке 2 , свидетельствует о ее высоком уровне в близком к границе ПДК, особенно в теплый период года.

Наиболее высокие значения отмечаются в летний

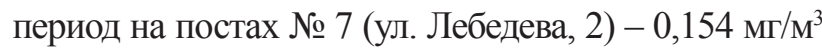
и № 1 (ул. Ростовская, 44) - 0,155 мг/ $\mathrm{M}^{3}$, что объясняется близостью автомагистралей с интенсивным движением транспорта, а также в развитой промышленной зоне. На правобережье (посты №№ 8-10)

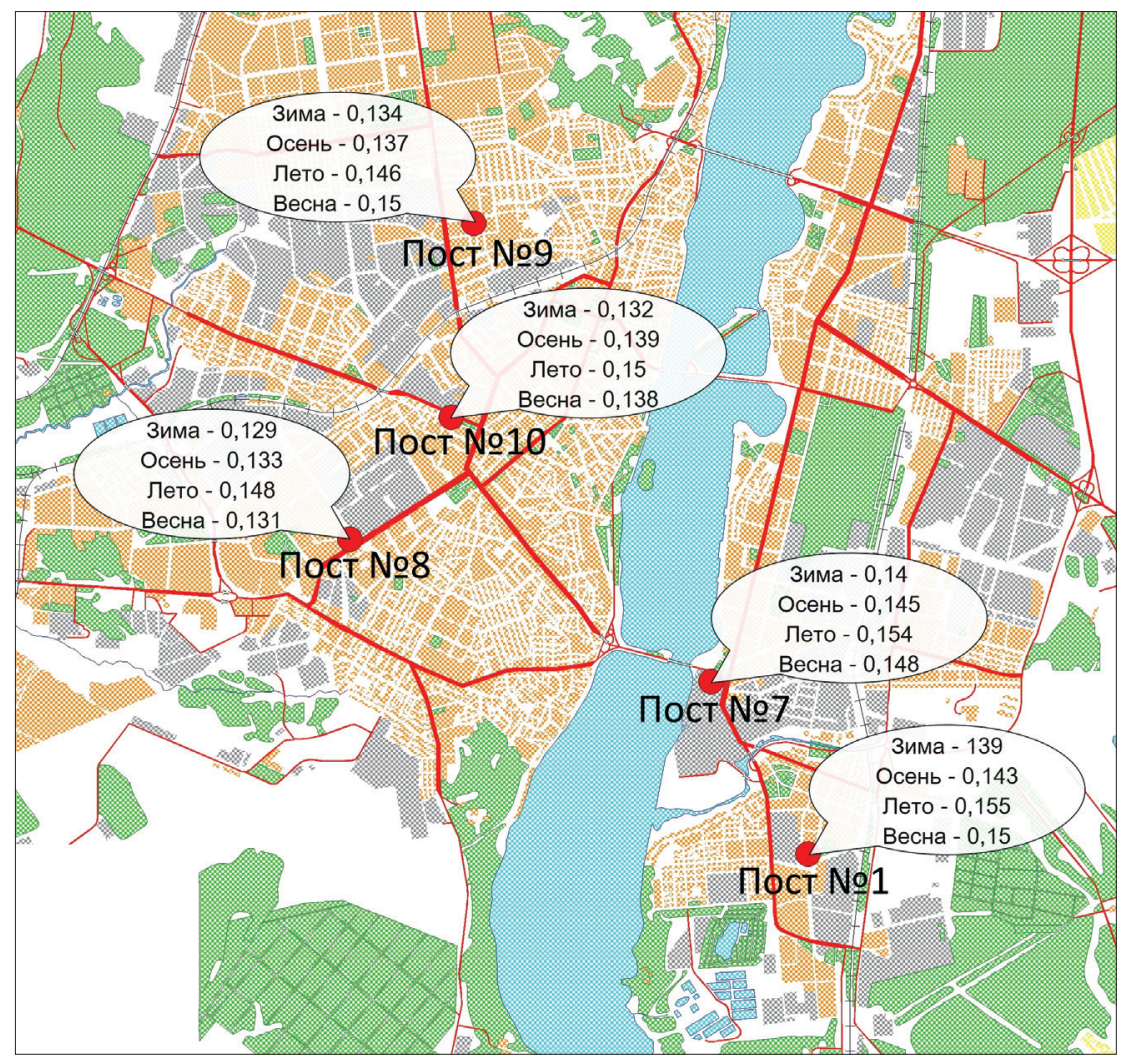

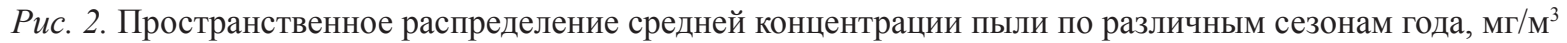

[Fig. 2. Spatial distribution of average dust concentrations over the different seasons of the year, $\mathrm{mg} / \mathrm{m}^{3}$ ]

${ }^{3}$ Доклад о состоянии окружающей среды на территории Воронежской области в 2018 году. Воронеж: Центр духовного возрождения Черноземного края, 2019. 240 с

${ }^{4}$ Доклад о природоохранной деятельности городского округа город Воронеж в 2017 году / Управление экологии администрации городского округа город Воронеж. Воронеж: 2018. 58 с.

Доклад о природоохранной деятельности городского округа город Воронеж в 2016 году / Управление экологии администрации городского округа город Воронеж, 2017. 55 с.

Доклад о природоохранной деятельности городского округа город Воронеж в 2015 году / Управление экологии администрации городского округа город Воронеж. Воронеж: 2016. 46 с.

Вестник ВГУ, Серия: География. Геоэкология, 2021, № 4, 77-87 
средняя концентрация пыли немного ниже и не превышает 0,15 мг/ $\mathbf{M}^{3}$.

При анализе выборки для каждого исследуемого года были определены средние за сезон значения концентрации загрязняющих веществ. Полученные значения легли в основу анализа средних концентраций загрязнения воздуха по сезонам за исследуемый период. Установлено, что наибольшая повторяемость загрязнения пылью (0,031 мг/ $\left.\mathrm{M}^{3}\right)$ приходится на летний период. Затем следует ве-

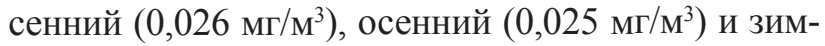

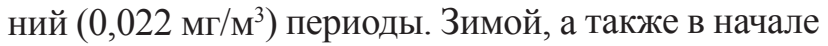
весны, земля покрыта снежным покровом, препят- ствующим загрязнению окружающей среды пылью. Осенью выпадают дожди. Высокий уровень запыленности в летний период объясняется как природными, так и антропогенными факторами. На территории Центрального Черноземья наблюдается тенденция усиления засушливости климата на фоне высоких температур, что способствует увеличению концентрации пыли в воздухе, также в Воронеже активно ведется строительство и наблюдается интенсивное автомобильное движение.

Пространственное распределение сернистого ангидрида $\left(\mathrm{SO}_{2}\right)$ на территории Воронежа, представлено на рисунке 3 .

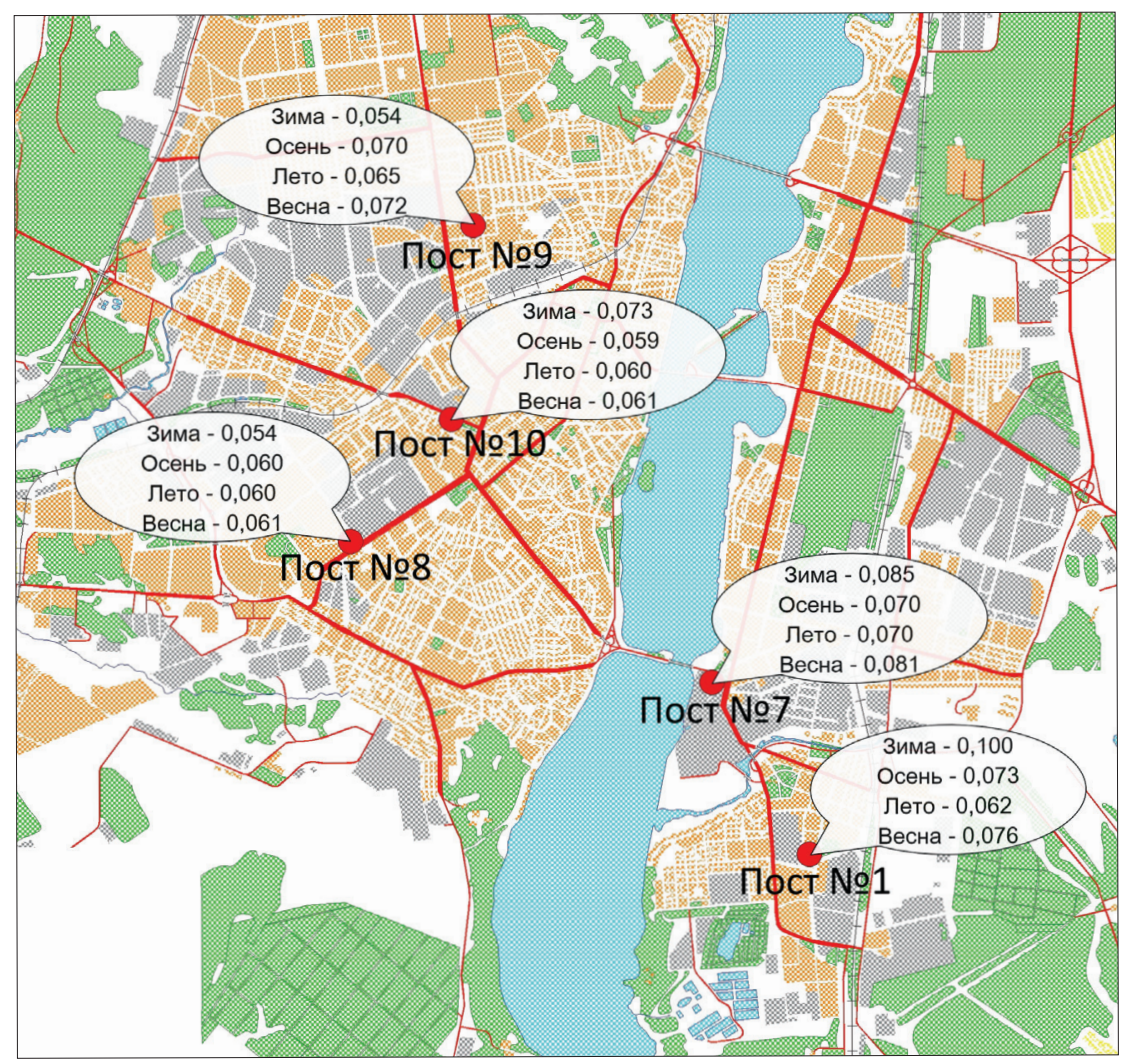

Puc. 3. Пространственное распределение средней концентрации сернистого ангидрида (диоксид серы $\mathrm{SO}_{2}$ ) в различные сезоны года, мг/ $\mathrm{M}^{3}$

[Fig. 3. Spatial distribution of the average concentration of sulphur dioxide (sulphur dioxide SO2) in different seasons of the year], $\mathrm{mg} / \mathrm{m}^{3}$

Из рисунка 3 следует, что концентрация в атмосфере диоксида серы наблюдается в холодный период года (осень, зима), о чем свидетельствует превышение ПДК. Наибольшая концентрация сернистого ангидрида регистрируется на посту № 1 (ул. Ростовская, 44) зимой и составляет $0,1 \mathrm{m \Gamma} / \mathrm{M}^{3}$, вдвое превышая ПДК.

Мониторинг за показателями сернистого ангидрида $\left(\mathrm{SO}_{2}\right)$ позволил установить, что максимум его приходится на зимний период $(0,053 \mathrm{M \Gamma /}$
$\mathrm{M}^{3}$ ).Если обратиться к процессу получения сернистого ангидрида ( $\left.\mathrm{SO}_{2}\right)$, то увидим, что в основном он образуется при сжигании серосодержащих веществ в воздухе. Резкий скачок выбросов сернистого ангидрида $\left(\mathrm{SO}_{2}\right)$ происходит зимний период за счет сжигания топлива отопительными системами, котельными и другими предприятиями.

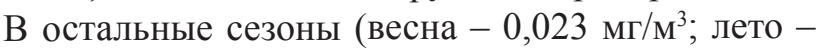
$0,025 \mathrm{M \Gamma} / \mathrm{M}^{3}$; осень $\left.-0,025 \mathrm{Mr} / \mathrm{M}^{3}\right)$ уровень загрязнения держится примерно на одном значении. 
Анализ средних сезонных концентраций окиси углерода за период 2015-2019 годов ${ }^{5}$ позволил установить, что повышенное значение этого загрязнителя в весенне-летний период

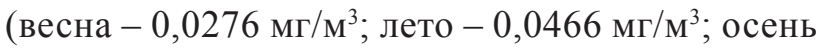

- 0,01 мг/ $\left.\mathbf{M}^{3}\right)$ обусловлено увеличением сгорания различных видов топлива автомобильным транспортом. Пространственное распределение концентрации окиси углерода, представлено на рисунке 4.

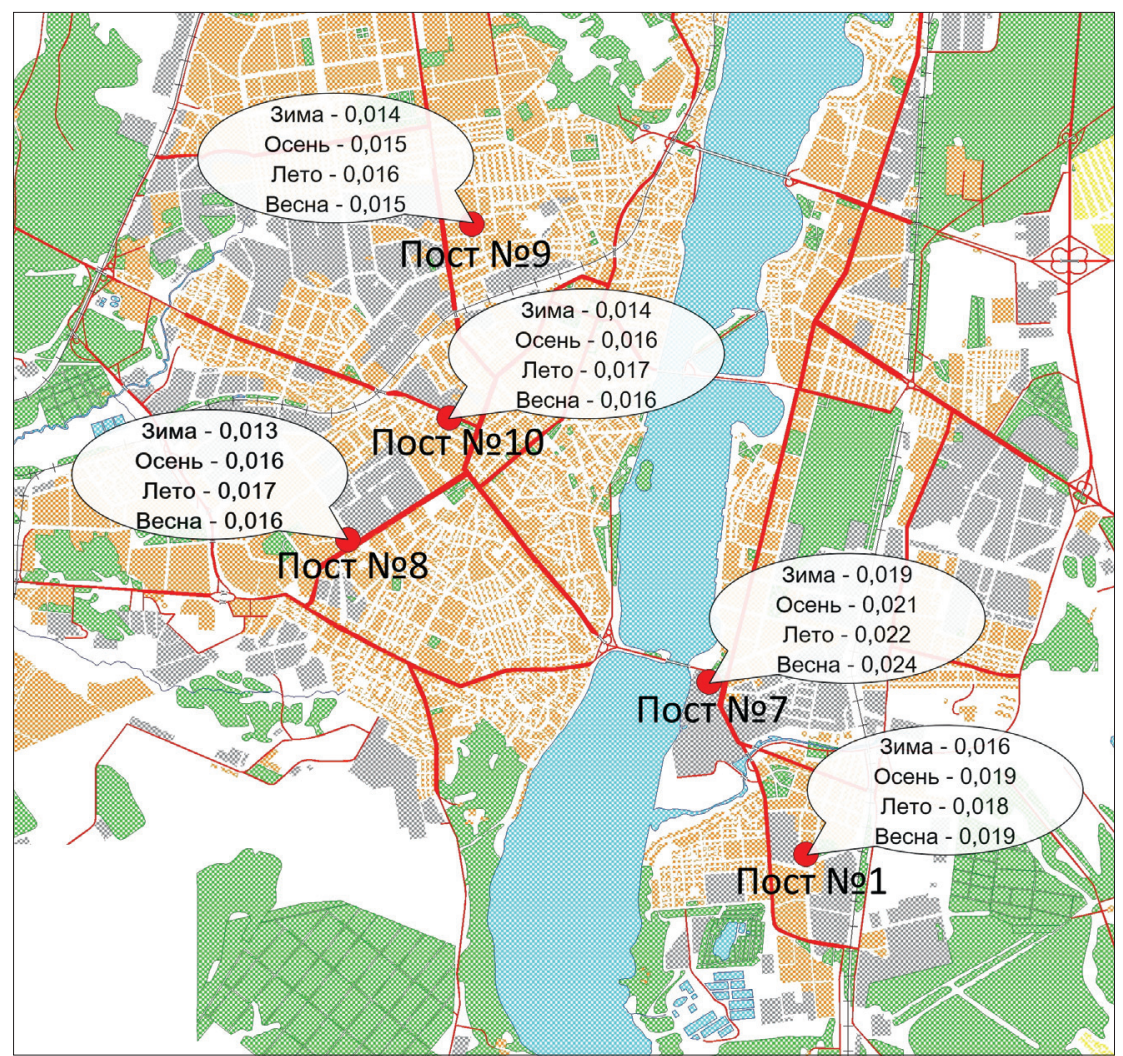

Puc. 4. Пространственное распределение средней концентрации окиси углерода по различным сезонам года, мг/м ${ }^{3}$

[Fig. 4. Spatial distribution of average carbon monoxide concentrations over the different seasons of the year, $\mathrm{mg} / \mathrm{m}^{3}$ ]

Из анализа рисунка 4 следует, что наибольшая концентрация окиси углерода отмечается в теплый сезон года. На правом берегу Воронежа (пост № 9 (ул. Л. Рябцевой, 51-Б), пост № 10 (ул. 9 Января, 49) и пост № 8 (ул. Ворошилова, 30)) - летом концентрация окиси углерода составляет $0,016-0,017 \mathrm{мг} / \mathrm{m}^{3}$, а на Левом берегу, на посту № 7 (ул. Лебедева, 2)

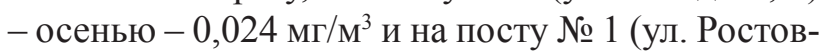
ская, 44) весной и осенью - 0,019 мг/ $\mathrm{M}^{3}$.

Диоксид азота образуется в основном при окислении оксида азота в атмосферном воздухе, при этом его количество, поступающее в атмосферу, практически постоянно. На территории го- рода Воронежа (рис. 5) концентрация двуокиси азота превышает ПДК в течение всего года.

На правобережье Воронежа (посты №№ 8-10) в течение года особенно летом, происходит незначительное превышение ПДК, концентрация двуокиси азота составляет $0,049-0,051 \mathrm{мг} / \mathrm{M}^{3}$. На левом берегу концентрация двуокиси азота значительно выше, особенно на посту № 7 (ул. Лебедева, 2), и составляет в течение года $0,055-0,072 \mathrm{Mr} / \mathrm{M}^{3} \mathrm{c}$ максимальными значениями концентрации летом. В зимний период $\left(0,047 \mathrm{мг} / \mathrm{M}^{3}\right)$ небольшое превышение нормы обусловлено сжиганием топлива отопительными системами. В среднем за теплый сезон

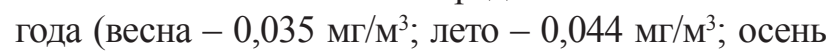

\footnotetext{
${ }^{5}$ Доклад о состоянии окружающей среды на территории Воронежской области в 2018 году. Воронеж: Центр духовного возрождения Черноземного края, 2019. 240 с.

Доклад о природоохранной деятельности городского округа город Воронеж в 2017 году / Управление экологии администрации городского округа город Воронеж. Воронеж: 2018. 58 с.

Доклад о природоохранной деятельности городского округа город Воронеж в 2016 году / Управление экологии администрации городского округа город Воронеж, 2017. 55 с.

Доклад о природоохранной деятельности городского округа город Воронеж в 2015 году / Управление экологии администрации городского округа город Воронеж. Воронеж: 2016. 46 с.
} 


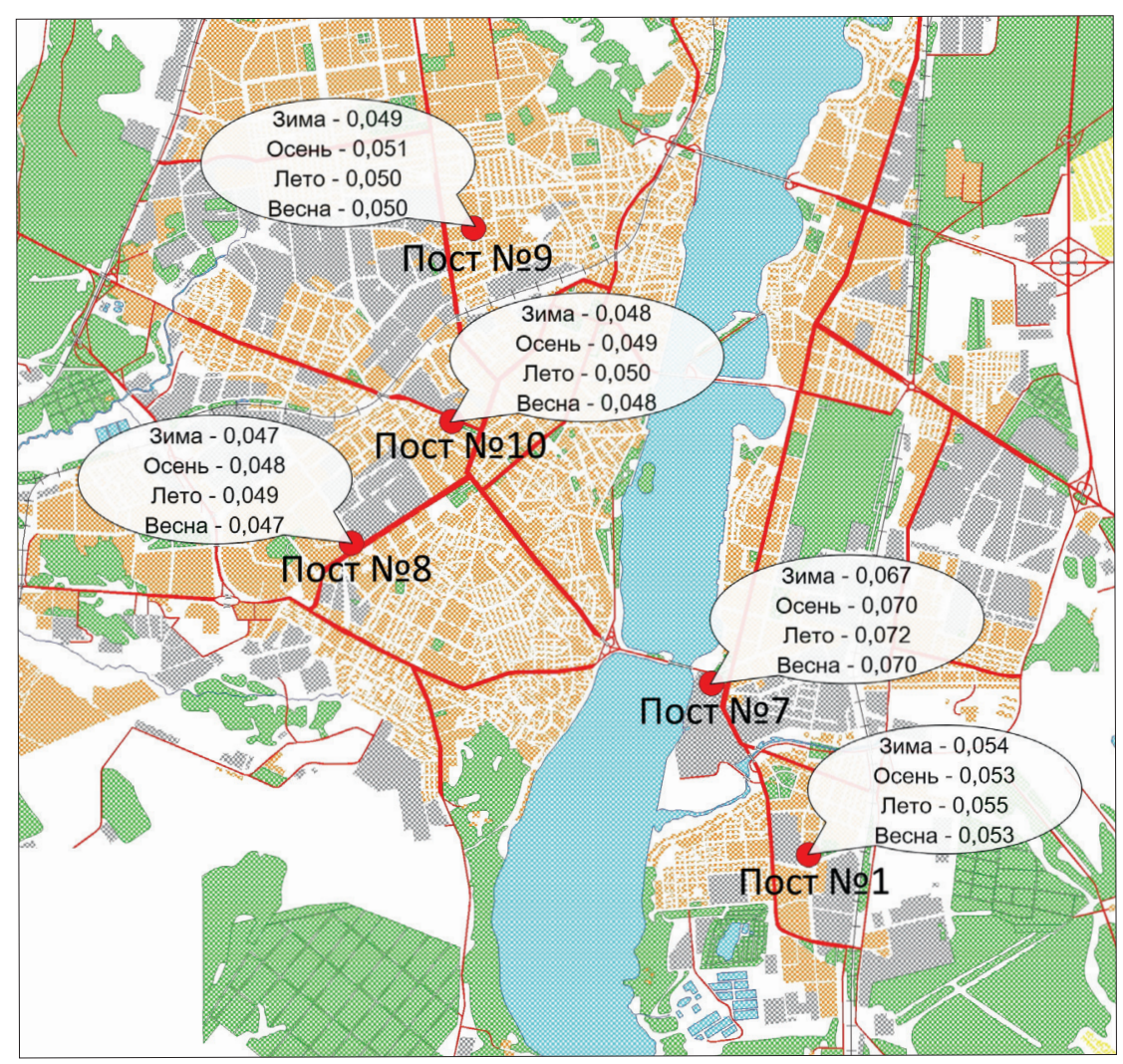

Puc. 5. Пространственное распределение средней концентрации двуокиси азота по различным сезонам года, мг/M ${ }^{3}$ [Fig. 5. Spatial distribution of average nitrogen dioxide concentrations over the different seasons of the year, $\mathrm{mg} / \mathrm{m}^{3}$ ]

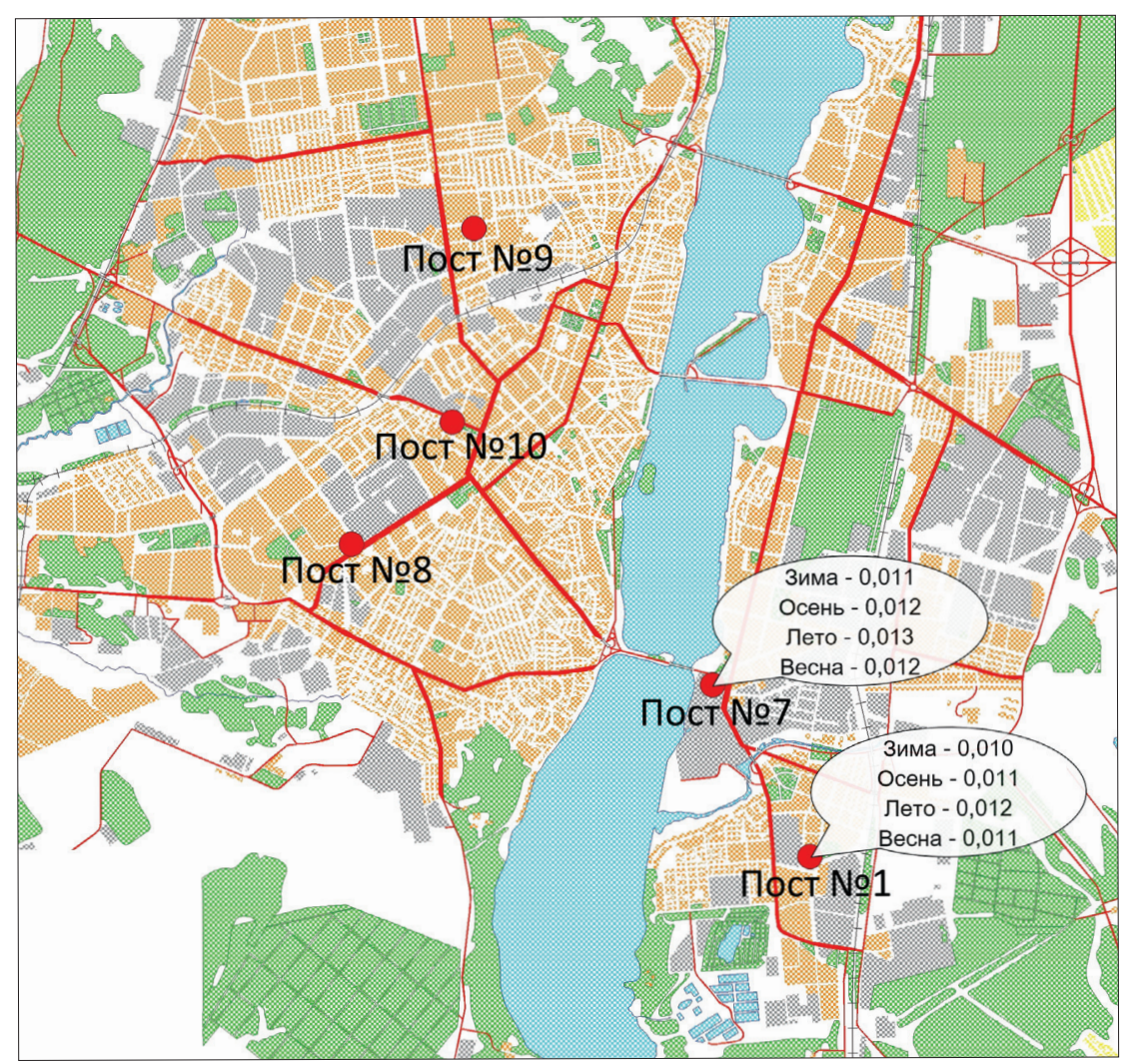

Puc. 6. Пространственное распределение средней концентрации фенола по различным сезонам года, мг $/ \mathrm{M}^{3}$ [Fig. 6. Spatial distribution of average phenol concentrations over the different seasons of the year, $\mathrm{mg} / \mathrm{m}^{3}$ ] 
$\left.-0,043 \mathrm{Mr} / \mathrm{M}^{3}\right)$ на территории города Воронежа отмечается высокая концентрация двуокиси азота.

Фенол - мощный источник загрязнения атмосферного воздуха города Воронежа. Производство асфальтобетона, машиностроительное производство, коксохимические заводы, шинное производство - основные источники поступления фенола в атмосферный воздух [9]. Пространственное распределение концентрации фенола представлено на рисунке 6.

В Воронеже высокий уровень загрязнения атмосферы фенолом происходит особенно летом. На постах № 1 (ул. Ростовская, 44) и № 7 (ул. Лебедева,

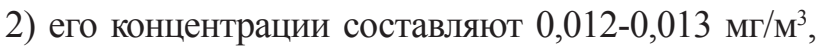
что превышает предельно допустимую дозу в 4 раза.

Средние сезонные концентрации фенола за период 2015-2019 годов ${ }^{6}$ указывают на то, что наблюдаются колебания вокруг среднего уровня (зима $-0,0052 \mathrm{Mr} / \mathrm{M}^{3}$; весна $-0,0028 \mathrm{мг} / \mathrm{M}^{3}$; лето
$-0,0124 \mathrm{Mг} / \mathrm{M}^{3} ;$ осень $\left.-0,0056 \mathrm{мг} / \mathrm{M}^{3}\right)$. Это, очевидно, обусловлено сезонной работой предприятий, являющихся источником выбросов фенола.

Формальдегид образуется в результате фотохимических реакций и процессов трансформации органических соединений. Автомобильный транспорт, химические предприятия, деревообрабатывающие фабрики (фанера, ДСП и ДВП, МДФ), мусоросжигательные заводы другие продукты горения - все это источники формальдегида в наружном воздухе [10]. Формальдегид - высоко опасное отравляющее вещество, влияющее больше всего на зрение. Он внесен в список канцерогенов, резко повышающий риск заболевания раком. Пространственное распределение формальдегида представлено на рисунке 7.

Анализ рисунка 7 свидетельствует, что в летний период, а именно на посту № 8 (ул. Ворошилова, 30), наибольшая концентрация формальде-

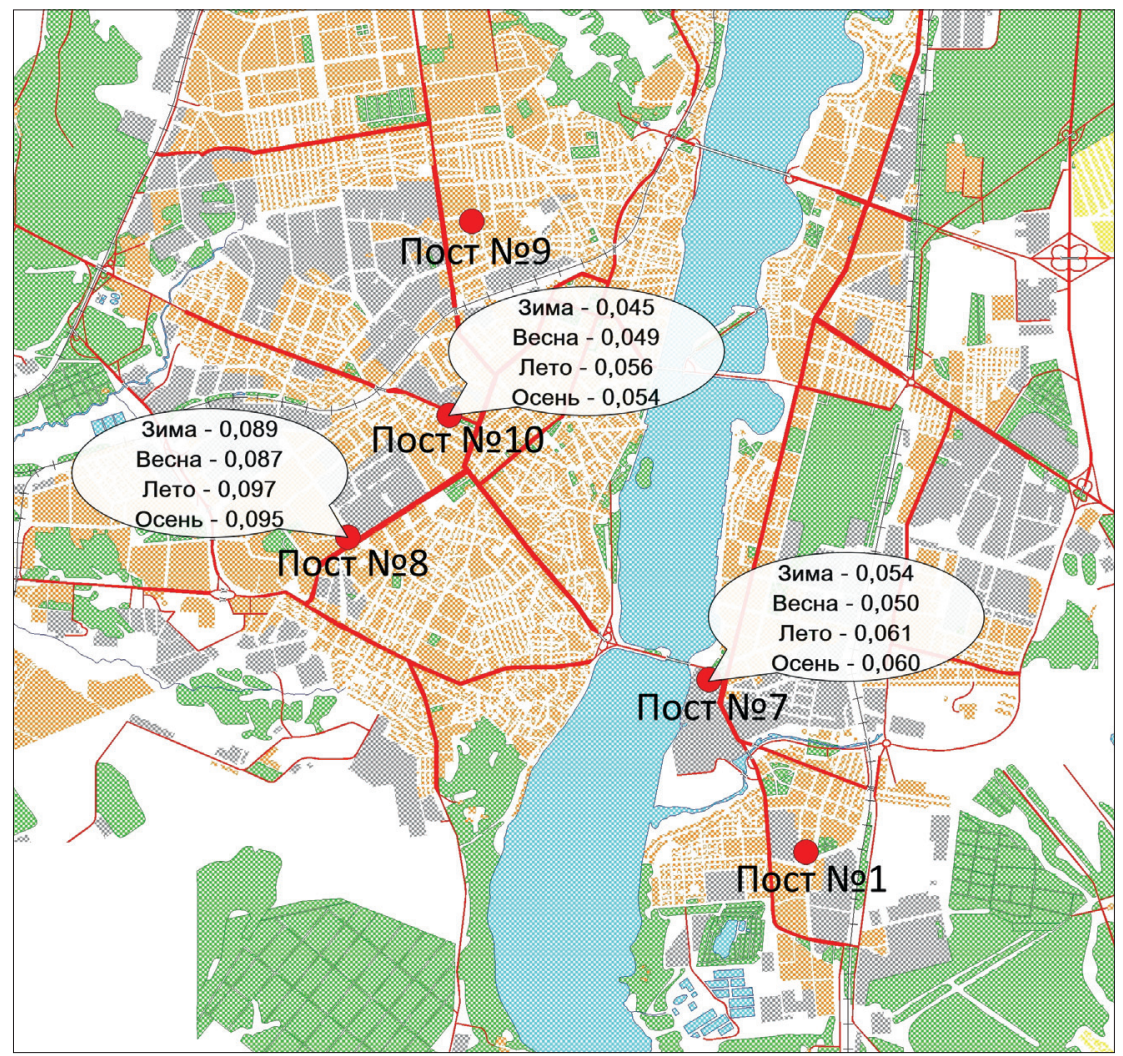

Puc. 7. Пространственное распределение средней концентрации формальдегида по различным сезонам года, мг/м³

[Fig. 7. Spatial distribution of average formaldehyde concentrations over the different seasons of the year, $\mathrm{mg} / \mathrm{m}^{3}$ ]

\footnotetext{
${ }^{6}$ Доклад о состоянии окружающей среды на территории Воронежской области в 2018 году. Воронеж: Центр духовного возрождения Черноземного края, 2019. 240 с.

Доклад о природоохранной деятельности городского округа город Воронеж в 2017 году / Управление экологии администрации городского округа город Воронеж. Воронеж: 2018. 58 с.

Доклад о природоохранной деятельности городского округа город Воронеж в 2016 году / Управление экологии администрации городского округа город Воронеж, 2017. 55 с.

Доклад о природоохранной деятельности городского округа город Воронеж в 2015 году / Управление экологии администрации городского округа город Воронеж. Воронеж: 2016. 46 с.
}

Вестник ВГУ, Серия: География. Геоэкология, 2021, № 4, 77-87 
гида - 0,097 мг/м³, превышающая ПДК. На посту № 9 (ул. Л. Рябцевой, 51-Б) сохраняются наиболее низкие концентрации формальдегида $-0,056$ мг/ $\mathrm{M}^{3}$, незначительно превышают ПДК. В целом в Воронеже концентрация формальдегида достигает величин выше нормы в промышленных районах.

Расчет средних сезонных концентраций формальдегида за период 2015-2019 годы показал, что средний годовой его уровень примерно одинаковый (зима $-0,055 \mathrm{Mг} / \mathrm{M}^{3}$; весна $-0,053 \mathrm{мг} / \mathrm{M}^{3}$; лето
$-0,051 \mathrm{мг} / \mathrm{m}^{3} ;$ осень $\left.-0,059 \mathrm{мг} / \mathrm{m}^{3}\right)$. Колебания в отдельные годы, видимо, связаны с непериодичностью работы предприятий, производящих эти выбросы.

Исследование особенностей пространственного распределения поллютантов в воздушном бассейне Воронежа в течение года, проводилось на основании расчета средних по месяцам значений ИЗА, результаты вычислений которых, представлены в таблице.

Таблийа

Среднемесячные значения ИЗА г. Воронежа

[Table. Monthly average values of the API in Voronezh]

\begin{tabular}{|c|c|c|c|c|c|}
\hline \multirow{2}{*}{ Месяц / Month } & \multicolumn{5}{|c|}{ ИЗА / AРІ } \\
\cline { 2 - 6 } & Пост 1 / Post 1 & Пост 7 / Post 7 & Пост 8 / Post 8 & Пост 9 / Post 9 & Пост 10 / Post 10 \\
\hline Январь / January & 8,5 & $\mathbf{1 5 , 8}$ & 7,6 & $\mathbf{5 , 3}$ & 7,5 \\
\hline Февраль / February & 10,5 & $\mathbf{1 6 , 3}$ & 7,9 & 5,5 & 8,2 \\
\hline Март / March & 9,2 & $\mathbf{1 4 , 8}$ & 6,7 & 5,1 & 7,1 \\
\hline Апрель / April & $\mathbf{1 3 , 6}$ & $\mathbf{1 6 , 5}$ & 9,1 & 6,2 & 9,2 \\
\hline Май / May & $\mathbf{1 2 , 7}$ & $\mathbf{1 7 , 7}$ & 9,3 & 6,6 & 9,3 \\
\hline Июнь / June & $\mathbf{1 1 , 5}$ & $\mathbf{1 9 , 9}$ & 9,4 & 6,3 & 9,6 \\
\hline Июль / July & $\mathbf{1 4 , 2}$ & $\mathbf{2 2 , 8}$ & 10,6 & 6,2 & $\mathbf{1 1 , 3}$ \\
\hline Август / August & $\mathbf{1 1 , 8}$ & $\mathbf{1 9 , 5}$ & 9,1 & 5,7 & 9,8 \\
\hline Сентябрь / September & $\mathbf{1 3 , 1}$ & $\mathbf{2 2 , 5}$ & 10,6 & 6,3 & $\mathbf{1 2 , 5}$ \\
\hline Октябрь / October & 8,8 & $\mathbf{1 5 , 4}$ & 7,8 & 4,8 & 7,9 \\
\hline Ноябрь / November & 8,5 & $\mathbf{1 3 , 3}$ & 7,3 & $\mathbf{4 , 6}$ & 7,3 \\
\hline Декабрь / December & 10,3 & $\mathbf{1 7 , 5}$ & 8,2 & 5,7 & 8,8 \\
\hline
\end{tabular}

Анализ таблицы осуществлялся на основании критериев риска, рекомендованных гигиеническими нормативами, согласно которым значение ИЗА от 11,1 и выше соответствуют критерию риска «Опасный», выше 10,1 - «Вызывающий опасение», выше 8,4 - «Вызывающий беспокойство».

На посту 1 (ул. Ростовская, 44), согласно результатам, представленным в таблице, в теплый период года, с апреля по сентябрь, уровень индекса ИЗА превышает значение 11,1, что соответствует критерию «Опасный». Уровень ИЗА в декабре $(10,3)$ и феврале $(10,5)$ соответствуют критерию «Вызывающий опасение», в ноябре $(8,5)$ и январе $(8,5)$ - «Вызывающий беспокойство». Значения индекса ИЗА на посту 7 (ул. Лебедева, 2), где сосредоточены предприятия ТЭЦ - 1 , АО «Воронежсинтезкаучук», ЗАО «Воронежский шинный завод» и проходит автомагистраль с интенсивным движением автотранспорта, в течение всего года в 1,5-2,0 раза превышали критериальные значения уровня «Опасный». Значения ИЗА, характеризующие состояние воздушного бассейна на посту 8 (ул. Ворошилова, 30), в течение года находились в пределах 7,7 - 9,3, что соответствовало уровню критерия «Вызывающий беспокойство», за исключением июля (ИЗА $=10,4)$ и сентября (ИЗА $=10,5)$, когда наблюдался уровень индекса ИЗА «Вызывающий опасение». Значения ИЗА на посту 9 (ул. Л. Рябцевой, 51-Б) в течение года не превышают критерий «Предельно допустимый», что свидетельствует о наиболее благоприятном состоянии воздушного бассейна. На посту 10 (ул. 9 Января, 49) значения ИЗА в течение года находятся в пределах критерия «Вызывающий беспокойство», за исключением июля и сентября, когда сохраняется уровень ИЗА - «Опасный».

\section{ЗАКЛЮЧЕНИЕ}

Проведенный анализ пространственно-временного распределения поллютантов в атмосферном воздухе города Воронежа позволил уста- 
новить, что очаги загрязнения имеют устойчивую локализацию рассеяния. Сильно выражено влияние функциональной структуры города на концентрацию загрязнений, которую можно рассматривать как антропогенный фактор. В теплый период года, с апреля по сентябрь, уровень индекса ИЗА в промышленных районах превышает значение 11,1, что соответствует критерию «Опасный». Наибольшая концентрация загрязняющих веществ наблюдается в районе размещения поста № 7 (ул. Лебедева, 2) в течение всего года в 1,5-2,0 раза превышает критериальные значения уровня ИЗА - «Опасный». Наиболее благоприятное состояние воздушного бассейна на посту 9 (ул. Л. Рябцевой, 51-Б). Здесь значения ИЗА в течение года не превышают критерий «Предельно допустимый». В Воронеже высокий уровень загрязнения атмосферы фенолом, особенно летом. На постах № 1 (ул. Ростовская, 44) и № 7 (ул. Лебедева, 2) концентрации фенола составляют 0,012-0,013 $\mathrm{Mг} / \mathrm{M}^{3}$, что превышает предельно допустимую норму в 4 раза. Концентрация формальдегида в отдельных районах города выше нормы.

Заметны сезонные колебания концентрации загрязняющих веществ, свидетельствующие об их связи с погодными условиями. Наибольшая концентрация диоксида азота регистрируется в холодный период, а пыли - летом, особенно при высоких температурах.

\section{СПИСОК ЛИТЕРАТУРЫ}

1. Акимов Л. М. Анализ временного распределения средних концентраций антропогенных примесей в Воронеже с учетом климатических показателей // Экология регионов, 2010, с. 8-12.

2. Акимов Л.М, Якушев А.Б., Куролап С.А. Геоэкологическая оценка загрязнения воздушного бассейна города Воронежа автотранспортом в зависимости от состояния атмосферы // Вестник Воронежского государственного университета. Серия: География. Геоэкология, 2011, № 2, с. 158-165.
3. Акимов Л.М, Виноградов П.М., Акимов Е.Л. Комплексная оценка экологической обстановки с учетом состояния атмосферы и функционально-планировочной структуры города // Вестник Воронежского государственного университета. Серия: География. Геоэкология, 2014, № 4, с. 57-67.

4. Акинин Н. И. Промылиленная экология: принциипь,, подходы, технические решения: учебное пособие. Долгопрудный: Издательский дом «Интеллект», 2011. 312 с.

5. Безуглая Э. Ю., Смирнова И. В. Воздух городов и его изменения. СПб.: Астерион, 2008. 254 с.

6. Безуглая Э.Ю., Смирнова И.В. Проблемы загрязнения воздуха // Крупнейшие города России. «Инженерные системыл» АВОК-Северо-Запад, 2002, № 2(6)-3(7), с. 35-36.

7. Безуглая Э. Ю. Чем дыишт промышиленный город. Јенинград: Гидрометеоиздат, 1991. 60 с.

8. Исаев Л.К. Воздействие на организм человека опасных и вредных экологических факторов. Метеорологические аспекты: в 2 т. / под ред. Л.К. Исаева. Москва: ПАИМС, 1997, Т.1. 512 с.

9. Кузнецова Е.Н. О состоянии окружающей природной среды г. Воронежа в 1998 г. Воронеж: ВГУ, 1999. $71 \mathrm{c.}$.

10. Куролап С.А., Епринцев С.А., Клепиков О.В., Федотов В.И., Стёпкин Ю.И., Мамчик Н.П., Корыстин С. С. Воронеж: среда обитания и зоны экологического риска: монография. Воронеж: изд-во «Истоки», 2010. 207 c.

11. Куролап С.А., Мамчик Н.П., Клепиков О.В. Оценка риска для здоровья населения при техногенном загрязнении городской среды. Воронеж: Воронежский гос. университет, 220 с.

12. Клепиков О. В., Куролап С. А., Седых В. А. Мониторинг загрязнения атмосферного воздуха и оценка канцерогенных рисков для здоровья населения города Липецка // Региональные геосистемы, № 2, с. 236-245.

Конфликт интересов: Авторы декларируют отсутствие явных и потенциальных конфликтов интересов, связанных с публикацией настоящей статьи.

Поступила в редакциию 02.09.2021

Принята к публикаџии 23.11.2021 


\title{
Pollutants and Carcinogens in the Atmosphere of Voronezh
}

\author{
L.M. Akimov ${ }^{\circledR}$, E. L. Akimov \\ Voronezh state University, Russian Federation \\ (1, Universitetskaya Pl., Voronezh, 394018)
}

\begin{abstract}
The purpose of the study is to provide a spatial and temporal analysis of the results of atmospheric air monitoring in the city of Voronezh.

Materials and methods. The article presents the results of analysis of daily monitoring data of "Voronezh Regional Center for Hydrometeorology and Environmental Monitoring" for the content of pollutants in the atmospheric air of Voronezh at 5 stationary observation stations operating in accordance with Guidance Document 52.04.186-89 for the period from 2015 to 2019.

The research methodology is based on a cartographic analysis of the distribution of the main pollutants and their comparison with the criterion values defined in the governing documents. Assessment of air pollution features was carried out using a comprehensive atmospheric pollution index (API) recommended by the requirements of hygienic standards HS 2.1.6.3492-17.

Results and discussion. The result of the study was to establish the features of spatial and temporal distribution of pollution fields by various pollutants, as well as studied their dependence on the seasons of the year. Mapping of the pollutants under study on the territory of Voronezh was carried out and their seasonal dynamics was established.

Conclusion. In the spatial distribution of the main pollutants on the territory of Voronezh there is a stable localization of pollution foci, due to the functional structure of the city. For some pollutants a strong dependence of concentration on the season of the year is expressed, which indicates the dependence of the concentration of pollutants on weather conditions and, above all, on the thermal regime.
\end{abstract}

Key words: concentration, pollutants, carcinogens.

Funding: "The research was carried out with the financial support of the Russian Science Foundation, project no. 20-17-00172".

For citation: Akimov L. M., Akimov E. L. Pollutants and Carcinogens in the Atmosphere of Voronezh . Vestnik Voronezskogo gosudarstvennogo universiteta. Seria: Geografia. Geoekologia, 2021, no. 4, pp. 77-87. (In Russ.) DOI: https://doi.org/10.17308/geo.2021.4/3753

\section{REFERENCES}

1. Akimov L.M. Analiz vremennogo raspredeleniya srednikh kontsentratsiy antropogennykh primesey v Voronezhe $\mathrm{s}$ uchetom klimaticheskikh pokazateley [Analysis of the time distribution of the average concentrations of anthropogenic impurities in Voronezh, taking into account the climatic indicators]. Ekologiya regionov, 2010, pp. 8-12. (In Russ.)

2. Akimov L. M, Yakushev A. B., Kurolap S. A. Geoekologicheskaya otsenka zagryazneniya vozdushnogo basseyna goroda Voronezha avtotransportom v zavisimosti ot sostoyaniya atmosfery [Geoecological assessment of pollution of the air basin of the city of Voronezh by motor transport, depending on the state of the atmosphere]. Vestnik Vorone- zhskogo gosudarstvennogo universiteta. Seria: Geografia. Geoekologia, 2011, no. 2, pp. 158-165. (In Russ.)

3. Akimov L.M, Vinogradov P.M., Akimov E.L. Kompleksnaya otsenka ekologicheskoy obstanovki s uchetom sostoyaniya atmosfery i funktsional'no-planirovochnoy struktury goroda [Comprehensive assessment of the environmental situation, taking into account the state of the atmosphere and the functional and planning structure of the city]. Vestnik $\mathrm{Vo}^{-}$ ronezhskogo gosudarstvennogo universiteta. Seria: Geografia. Geoekologia, 2014, no. 4, pp. 57-67. (In Russ.)

4. Akinin N.I. Promyshlennaya ekologiya: printsipy, podkhody, tekhnicheskie resheniya: uchebnoe posobie [Industrial ecology: principles, approaches, technical solu-

(C) Akimov L. M., Akimov E. L., 2021

$\triangle$ Leonid M. Akimov, e-mail: ak163@bk.ru 
tions: a textbook]. Dolgoprudny: Izdatel'skiy dom «Intellekt», 2011. 312 p. (In Russ.)

5. Bezuglaya E.Yu., Smirnova I. V. Vozdukh gorodov $i$ ego izmeneniya [The air of cities and its changes]. Saint-Petersburg: Asterion, 2008. 254 p. (In Russ.)

6. Bezuglaya E. Yu., Smirnova I. V. Problemy zagryazneniya vozdukha [Problems of air pollution]. Krupneyshie goroda Rossii. "Inzhenernye sistemy» AVOK-Severo-Zapad, no. 2 (6)-3 (7), 2002. (In Russ.)

7. Bezuglaya E. Yu. Chem dyshit promyshlennyy gorod [What an industrial city breathes]. Leningrad: Gidrometeoizdat, 1991. 60 p. (In Russ.)

8. Isaev L.K. Vozdeystvie na organizm cheloveka opasnykh i vrednykh ekologicheskikh faktorov. Meteorologicheskie aspekty: v 2 t. / pod red. L. K. Isaeva [The impact of dangerous and harmful environmental factors on the human body. Meteorological aspects: in 2 volumes]. Moscow: PAIMS, 1997, vol.1. 512 p. (In Russ.)

9. Kuznetsova E.N. O sostoyanii okruzhayushchey prirodnoy sredy g. Voronezha $v 1998 \mathrm{~g}$. [About the state of the natural environment of Voronezh in 1998]. Voronezh: VGU, 1999. 71 p. (In Russ.)

\section{Акимов Леонид Мусамудинович}

кандидат географических наук, доцент, зав. кафедрой природопользования факультета географии, геоэкологии и туризма Воронежского государственного университета, г. Воронеж, Российская Федерация, ORCID: 0000-0003-0749-1976, e-mail: ak163@bk.ru

Акимов Евгений Леонидович

кандидат географических наук, преподаватель кафедры природопользования факультета географии, геоэкологии и туризма Воронежского государственного университета, г. Воронеж, Российская Федерация, ORCID: 0000-0003-4909-4290, e-mail: akimovvsu@gmail.com
10. Kurolap S.A., Epintsev S.A., Klepikov O. V., Fedotov V.I., Stepkin Yu. I., Mamchik N.P., Korystin S.S. Voronezh: sreda obitaniya $i$ zony ekologicheskogo riska: monografiya [Voronezh: habitat and environmental risk zones: monograph]. Voronezh: izd-vo «Istoki», 2010. 207 p. (In Russ.)

11. Kurolap S.A., Mamchik N.P., Klepikov O. V. Otsenka riska dlya zdorov'ya naseleniya pri tekhnogennom zagryaznenii gorodskoy sredy [Assessment of the risk to public health in case of technogenic pollution of the urban environment]. Voronezh: Voronezhskiy gos. universitet, 220 p. (In Russ.)

12. Klepikov O. V., Kurolap S.A., Sedykh V.A. Monitoring zagryazneniya atmosfernogo vozdukha i otsenka kantserogennykh riskov dlya zdorov'ya naseleniya goroda Lipetska [Monitoring of atmospheric air pollution and assessment of carcinogenic risks to the health of the population of the city of Lipetsk]. Regional'nye geosistemy, no. 2, pp. 236-245. (In Russ.)

Conflict of interest: The authors declare no information of obvious and potential conflicts of interest related to the publication of this article.

Received: 02.09.2021

Accepted: 23.11.2021

Leonid M. Akimov

Cand. Sci. (Geogr), Associate Professor, Head of the Department of Nature Management, Faculty of Geography, Geoecology and Tourism, Voronezh State University, Voronezh, Russian Federation, ORCID: 0000-0003-07491976, e-mail: akl63@bk.ru

Evgeniy L. Akimov

Cand. Sci. (Geogr), Lecturer of the Department of Nature Management, Faculty of Geography, Geoecology and Tourism, Voronezh State University, Voronezh, Russian Federation, ORCID: 0000-0003-4909-4290, e-mail: akimovvsu@gmail.com 